III期, IV期 7 例から予後判定因子を考えると, 初診時 1 歳末満, 副腎原発以外, 未梢 リンパ 球数 3,000 以上, LDH 值1,000単位以下の症例が生存例であり，予後推定 上重要である点を強調し, 最後に吕期例で全摘不能例に 対し, Reduction Surgery が有効であった症例を紹介し た.

\section{來長のまとめ}

河野 澄男

III-115（昭和大学外科, 李他 7名）小児に於ける手 術侵褧前後の血液凝固系の变動をフィブリノーゲンを中 心として検討を加えた. 先す測定法であるが，従来のチ ロジン法にくらべ稲田法によるフィブリノーゲン測定法 で一番の利点は測定終了まで 2 分以内といら短時間で測 定が可能なことと clottable fibrinogen を正確に反映す る点である. 特に重要な点は新生児, 未熟児のフィプリ ノーゲンの手術浸嘎に対する反応が年長児にくらべ軽度 に上昇する点である．尚検討中であるが肝臓をはじめ生 体代謝の未熟性が関与するものではないかと推測してい る. 血液凝固系を論ずる場合, 種々の因子が存在するの で結論ずけることはむつかしく今後の椧討が必要である 丂.

III-116（静岡こども病院, 河野他 5 名）小览の肝胆 道系疾患に対して半減期の短い, 大量投与可能な, 従っ てイメージングの良好な ${ }^{99_{\mathrm{m}}} \mathrm{Tc}-\mathrm{P} . \mathrm{I}$ を使用して診断に 有用であったと述べている. 先天性胆道閉鎖症で肝影は 早く描出したが，240分経過しても胆管，胆の5, 腸管 への排出は全く認めず，乳児朋资では肝影の描出は早い が胆管, 胆のう，腸管への排出は緩慢であったが全例腸 管への排出が先天性胆道閉鎖症と異なる点であったと報 告した，高橋氏（千葉大小児外科）は本剂の有用性を認 めても胆道閉鎖症と乳児肝炎の鑑別には充分でないと述 ベている. 胆道扗張症例では肝内肝外胆管像はともに鮮 明な像が得られた。

III-117（清瀬小児病院, 石田他 6名）小児外科領域 に於ける肝シンチグラムで, ${ }^{99 \mathrm{~m} T c}$ phyfate を使用して 96症例, 177回施行した. 肝内限局性病変, 更にはび漫 性肝疾患等多数の症例に対し診断的に有用であったと報
告している. 特に先天性胆道閉鎖症の経過観察などでは 本剂の方が有効であると述べている.

III-118（北大第 1 外科, 秦他10名）小児肝癌に 対す る治療成績についての問題点についてあらゆる面から検 討された. 特に組織型, 病期, AFP 值等の面から生存 例について述べている. 後半10年間に於ける治療方針に 著変はないが, 術後 Iカ月〜 2 カ月は AFP 值半減期を めって，その後は AFP 值の上昇をるって再発を診断 し, 化学療法, その他の治療を開始すると述へている. AFP 值半減期は肝切除手術後の根治珄を示す有力な指 標とされている. 半減期が3.5日でも術後転移を来たし 死亡した症例の報告すあり，AFP 值の変動については 充分の注意を要する，岡松氏（昭和大学外科）より再発 小児肝癌に 対する持続動注治療法についての質問があ り, 秦は腫瘍の縮小奻果は mild であったがこの症例は 末期であったのでそのよらな結果となったと報告した。

III-119（名古屋保健大，山口他 8名）神経芽細胞腫 眼窝転移の 2 例に computed Tomography (C. T.) を施 行し興味ある所見を報告している. C. T. の所見で眼窝 部の軟部組織に転移巣が出現したと報告したが，同様の 症例を経験菁心石田氏（清瀬小児病院）は骨転移かある いは骨膜部の変化ではないかの質問があった. 山口氏は 骨膜からの連続性は認めなかったと述べ，C．T．での分 析でも今後更に検討の必要があると考えられた。

III-120（昭和大学外科，四ッ谷他 6 名）神経芽細胞 喱 7 例の詳細な臨床検討がなされた。. 年令は 1 歳未満 4 例, $2 \sim 7$ 歳 3 例, 原発巣は副腎 4 例, 骨盤炡 1 例, 不 明 1 例, 病型 III 期 2 例, IV期 4 例, IV-S 期 1 例, 生存 例では術前 LDH 檤は全例1,000以下で末梢りンハ球数 は3,000以上であり術前化学療法が全例に行われていた. 神経芽縕胞腫の予後判定因子としては LDH 值, 末梢り ソパ球数がある程度の指標になると報告している。

又面期の尰啕全剔出不能例に拈いて子 reduction surgery が著効した例むあり進行例でむ積極的に手術を施 行していると述べている.

\title{
第V会場 午前の部
}

消化管出血 $(\mathbf{V}-81 \sim 85)$ 座長 勝見 正治

V-81. 診断の困難であった消化管出血の 4 例 自治医科大学消化器外科
村上 幸司, 金城 康夫, 川田 克也

天目 純生, 笠原小五郎, 宮田 道夫 柏井 昭良, 森岡 恭彦 
近年消化管出血に対して菣急内視鏡検査は，多くの施 設においてルチーンに行なわれており，高い診断率が得 られている. しかし出血部位の解剖学的制約や患者側の 問題さらには出血の程度等によっては血管造影法による 方がより有効であることは諸家の報合のと括りである.

我々も多くの場合は内視鏡で出血部位を確認し得ている が上述の様な制約の為にそれが不可能で，最終的に血管 造影で診断した症例を経験した. 今回はそれらの 4 例に ついて報告する．症例 1 は総胆管癌の診断の元に総胆管 切除・肝管空腸吻合術後 8 日目に大量下血. 血管造影法 にて右肝動脈偽動脈瘤上りの出血と診断, 手術時飞止 血. 症例 II は十二指晹球部後壁潰湟よりの出血で胃切術 B - I 法施行後 4 週問目再度吐下血 と腹腔内出血. 血管 造影にて胃十二指腸動脈よりの出血と診断手術的に止 血. 症例 III 復する大量吐下血の為近医にて胃切術 B -II 法を施行後む止血 せず再開腹したが出血源不明. 当院転科し緊急血管造影施行，十二指腸下行脚下部に腫 燩陰影がみられ，前医のX線検查にてる同部に異常䧔影 あることより出血部位と診断，腫煬を切除した．十二指 腸平滑筋腫であった，症例IV下血を主訴とし入院. 他の 検査で診断つかず外来経過観察中，下血と左下腹部痛に て緊急入院，血管造影施行. 空晹の動静脈形成異常によ る出血を疑い手術施行. 手術中も, 切除標本の病理学的 険查にてもそれを確認，以上の如く，胃切除術等に上り 消化管順路の変更を受け大症例や小腸に病変を有する症 例で出血量が一定を超劣るるの，或いは血管造影により 出血性病変の確認できるむのについては，内視鏡検査よ りも血管造影法による方がより迅速啇確な情報が得られ

る. 適応を選べば，有効な診断法と考えられる.

\section{V-82. 脑外科疾患と消化管出血の検討}

\section{国立習志野病院外科}

伊藤 文雄，香田 真一，鈴木 秀

相原 秀茂, 若月 岩雄, 線貫 重雄

同脑外科 細井 湧一, 佐藤 政教

文隆雄，伊達 裕昭

国立習志野病院外科において最近 3 年間で16例に消化 管出血の合併をみ，ちち非開腹例 9 例中 8 例が死亡し， 開腹例では 7 例中 2 例を失い 5 例を救命した。 この開腹 例 7 例飞ついて検討した．症例恃全て男性で血腫除去術 が行われ大部分が開頭術後約 1 週間以内に消化管出血が みられた，出血は下血が多く3 例がショック状態とな り，その他の例とともに保存的療法により止血出来す外 科的治療にきりかえた，出血部位は胃潰瑒 3 例，十二指
腸潰瘍 3 例，不明 1 例で 6 例に胃切除術を行った，大量 の出血が続くものは保存的治療で救命することがむずか しく，期を失うことなく外科的治療にきりか光るべきと 考える.

V-83．急性消化管出血に対するパソプレッシン全身 投与法について

広田胃腸病院 大矢 和光, 広田 和俊

上部消化管出血に対する保存的止血法として，我々は Vasopressin 経末梢静脈全身投与を行ない，従来の止血 剤にまさる止血効果を得たので報告する。

Vasopressin 投与法は，消化管出血症例に対し通常の 止血療法を行なら一方, Vasopressin 100単位を $5 \%$ ブト ウ糖液 $500 \mathrm{ml}$ にて希釈，7〜8時間にて末梢静脈より 投与した。投与症例は，昭和52年 6 月より本年 9 月まで の14カ月間に総計24例，26回の大量出血エピソートに対 して行ない，内訳は食道静脈瘤 7 例，Mallory-Weiss 症 候群 1 例，消化性潰瘍 6 例，AGM 1 例，胃癌 5 例，潰 瘍性大腸炎 2 例，術後出血 2 例で，そのうち有效症例は 17例，18エピソードであり，有効率は69.2\%であった。 疾患別では食道静脈瘫出血を除いた有効率は76\%にの ぼり，撰択的動脈内投与の欧米の成績に匹敵する. しか し，静脈瘁症例では $57 \%$ 之成績が悪い，一方 Vasopressin 使用後の経過をみると，食道静脈瘤症例で救命率25\%と 低く，高度の肝障害に起因していると考克られる，又非 静脈瘤症例でも再出血率が50\%と高く，再出血までの日 数は最長 10 日, 最短 3 日で平均 5.3 日 と短く, 止血後早 期に状熊の改善を待ち適切な処固が必要と考える.

Vasopressin 投与による副作用としては，高血圧，除 脈，不整脈等が報告されているが，我々の経験した副作 用は， 4 例に収縮期圧で $180 \mathrm{mmHg}$ を越克る高血圧を， 乏尿を一例に，徐脈を再投与時に一例認めたが，いずれ もその後重䉣な合併症とはならなかった。

以上述べたよらに，Vasopressin 全身投与は，撰択的 動脈内投与と同様の止血効果が得られるが，再出血の危 険が大く，早期に適切な処置が望まれる．又副作用と して高血圧，乏尿，徐脈を経駼 し，投与中はこれらの check を行なら必要がある. しかし，簡易な手技にて確 実な止血効果の得られるこの方法にて, elective operation が可能となり手術成績の向上につながると考える.

V-84. 十二指晹球後謴瘍大量出血に対し，搼頭十二 指腸切除を施行した 1 症例について 新潟大学第 1 外科 佐々木広憲, 松木 久 田宮 洋一, 武藤 輝一 
十二指腸球後部潰㻛は，一般に幽門輪から，5cm 以

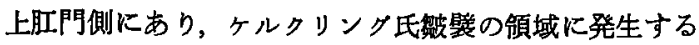
潰㻛之されている. 私共は十二指晹球後部潰瘍の大量出 血に対し，脺頭十二指腸切除を施行した症例を経験した ので報告する。

症例は73歳男子で，吐下血のため某病院に入院し，内 視鏡挨査で 3 個の十二指腸潰瘍之同部に血餅の付着が確 認された. 最初の手術として潰湯一個を含む広範囲胃切 除㭪 B I 法が行なわれたか，十二指腸下行脚になお， 2 個の潰場が牫存し，これらの狫却と縫合，及び胃十二指 腸動脈の結禁が加えられた。

しかし第 5 病日より再出血があり，第九病日に当科に 転科したが，保存的に止血さ机党ず，翌日緊急手術を行 った.

手術所見：脺頭周囲の血行が豊富で出血しやすく，組 織がるく，血管の結等等では潰煌からの出血は止血さ れえず，出血潰瘁を含め，脺頭十二指腸切除を施行し た. な掤䉼端は，全身状態不良につき外瘦とした。

十二指腸球後部潰演は切除困難な事が多く，この場 合，一般には嘳湯を惦置し，胃切除 B I 法が行なわれる 事が多く，これにて止血される事す多いが，教室では，

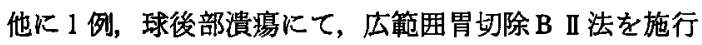
し，㳂置した潰疡の穿孔により死亡した症例を経験して いる.

私共は消化性潰煌出血に対し潰煌部を含めての胃切除 を原則としているが，特に噴門潰沮や球後部潰場の場

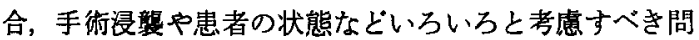
題恃多い。

本症例は残念ながら，腹腔内感染によるエンドトキシ ソショックにより，4カ月後に死亡したか，私共はここ に呈示したよらな球後部潰晹からの大量出血に対して は，場合によっては，粸頭十二指腸切除といった思い 切った処置も必要と考えている.

V-85. 出血性消化性暴清の手術適底

東京女子医科大学外科 斎藤正光, 村田 順, ウィ・キム1 嶋田誠, 中川 隆雄, 岩崎 裕 倉光 秀磨, 太田八重子, 織畑 秀夫 急性上部消化管出血例飞批るる消化性潰場の頻度は高 く，その手術適応む臨床上重要な問題である.1969年 1 月～1977年12月の間に東京女子医科大学外科に拈いて 147例の急性上部消化管出血例を経験したか，その75.5 \%を占める111例の消化性潰瘍について手術適応の面か
ら検討した。

手術時期（発症上り48時間以内を早期，3〜7 日を中 期，8日以降を晚期とした)，輸血所要量/日，ショック 指数 (脈拍数/最高血圧, 以下 SI と略す), 血液指数 （白血球数/血色素量 $\times 10^{3}$ ，以下 BI と略す）等から手 術適応の criteria の検討を試みた。

手術前の輸血所要量/日との関係をみると早期手術と 中期手術間，中期手術と晚期手術間淿輸血量に有意差 を認め，早期と中期の境は $1,000 \mathrm{ml}$ ，中期と晚期の境は $500 \mathrm{ml}$ となった． SI ・ BI の経時的変化をみると早期手 術では1.0以上への変化を示し, 中期では1.0以上から 1.0 以下への变化を示し，晚期や非手術例では1.0以下の 範围内での変化を示していた。

そこで輸血所要量/日，SI ・ BI の経過と早期，中期， 晚期手術例，非手術例との関連を検討したが，上記 3 因 子の交互の関連はみられなかったが，全体としてまた 3 因子各々単独で早期，中期，晚期手術，非手術の分布に 関連性を認めた，更に潰崵底の露什血管存在例の死亡率 は手術例に有意低孪であったことが知りえた。

以上から長尾の transfusion test に類似した輸血所要 量/日，SI ・ BI の経過の組合せから手術時期の判定を行 いらること，また漬湯底露出血管は手術適応の一指標と なりらること等が判明した。

\section{坐長のまとめ 勝見 正治}

このセッションは消化管出血に関する演題ばかりで， 活溌な討論が行わ㧈たＶＶ-81の自治医大村上氏他の 「診断困難の消化管出血の 4 例」は，術後の十二指腸球 後部潰瘍，空晹筋腫など内視鏡で診断困難例に対して血 管造影で，出血部位のみならず質的診断が可能であった といら報告で, $\mathrm{V}$ 一84の演題ともからんで術後の球後部 溃湢出血例に質疑が集中した，本例で胃十二指腸動脈結 㨞が止血に有効であったとのことから，新大 1 外松木氏 より，潰瘍の部位と血管結紮の部位とが質問され，幽門 輪より $3 \mathrm{~cm}$ 肛門側の潰瘍で, 胃十二指腸動脈を近位, 遠位の 2 カ所で結惄したとの答学があり，東京女子医大 杮原氏より，術後の血管造影につき質問があり，演者か ら施行していないといら解答があった。

$\mathrm{V}$-82の国立習志野病院伊藤氏他の「脳外科疾患と消 化管出血」では，ストレス潰湯らしきすのと消化性潰瘍 の再燃らしきものが混在した症例で，7例中 5 例が手 術で救命出来たとの報告で, 新大 1 外松木氏よりストレ ス潰瘍に対して胃重全摘で出血病变部を切除出来るるの が多く，迷切を加える術式がよいことを述へ，胃全摘を 
要する症例があったかどうか質問があり，演者の症例は すべて普通の切除範聿で十分であったとの答えがあっ た.

$\mathrm{V}$-83の広田胃腸病院大矢氏らの「急性消化管出血に 対するパソプレッシン全身投与法」は，ゼングスターケ ソチューブ, 胃内冷水洗浄とかの一般止血法を講じた上 に，本剤100単位を $5 \% ふ ゙ と ゙ う$ 糖 $500 \mathrm{ml}$ に薄め， $7 \sim 8$ 時間で投与すると，85\%の症例で $2 \sim 3$ 時間以内に効果 があらわれ，又，反面繄急手術選択の早期判定にも役立 つとの報告であった。

$\mathrm{V}$ 一84の新大 1 外佐々木氏よりの，「術後十二指腸球 後部潰瘍よりの出血に対し膵頭十二指腸切除を行った症 例」は，色々示唆に富んた症例で，質問が集中した．横 浜市大 2 外杉山氏, 広田胃腸病院廣田氏他上り, 術前の 胃酸，ガストリン值及び剖検での Z-E 症候群の所見な ぞについて質問があり，本例は初回手術が他病院で而も 出血が続いた状態であり，充分検索されなかったが，切 除標本て Z-E 症候群の所見はなかったとの解答があっ た，又広田氏より膵十二指腸切除上り迷切十幽成がよい のではないかとの発言があったが，判定は今後の問題で あろ5.

$\mathrm{V}$-850東京女子医大斉藤氏他からの「出血性消化性 潰瘍の手術適応」では, ショック指数と血液指数とから 緊急手術適応を決めようとする試みであって，実際には 輪血の為に指数がどのように修飾されるか，又検血の間 隔はどれ位がよいかなどの問題が残されているよらに感 ずるが，極めてュニークな研究であった。

消化性漬瘍 I (V-86 89) 座長 白鳥 常男 V-86. 最近12年間における穿孔性胃十二指霛溃瘍例 の模討

名古屋第 1 赤十字病院外科 岩瀬 正紀 近年胃十二指腸潰瘍に対する内科的治療の向上は著し いものがあるが，穿孔例に遭遇するのも稀でない，我々 は過去 12 年間に86例の穿孔例を経験したので種々の観点 より検討する．過去 12 年間に経験した胃十二指腸潰煌切 除例は644例で穿孔例は86例13.4\%であった．年龄分布 は十二指腸溃㳻穿孔で20代〜30代に，胃潰湯穿孔で50代 〜 60代にピークを認めた。男女比は77対 9 で男性が多か った，季節別発生頻度では夏期に少く，発症時刻では午 前中に症状自覚したものが50例を占めた，発症より手術 迄の時間は55例が12時間以内であった，既往の胃腸症状 をもたない患者が33例ありこれは若年者十二指腸潰瘍穿 孔例であるものが多かった，険査所見として白血球数は
66例74.4\%に10,000以上を認めた，腹部X線写真施行例 59例の中で腹腔内遊離ガス像を認めたのは46例であっ た. 穿孔部位としては十二指腸潰愓穿孔では十二指腸前 壁中央がもっとも多く，胃潰湯穿孔例では胃体部前壁小 弯よりがもっと多かった. 術式では, 胃切除83例，そ の他 3 例であった，術後合併症として繾合不全が 5 例あ ク，イレウスは 4 例，その他 4 例であった. 死亡例は 5 例 $5.8 \%$ であり，それぞれ検討してみると，自覚症状発 現から手術迄の時間の延長，高年齢，重篤合併症，の各 因子が直接死亡に影響している為，以上の因子をるつ症 例には，なるべく手術侵襲を少なくし，術後管理をより 慎重に行うことが必要であると考える.これらの因子を るたない症例は時期を逸することなく，より早く診断を 下し，すみやかに手術を施行することにより救命し得る ので，患者の一般状態を考虑し，術式にこだわることな く対処すべきであると考える.

V-87. 穿孔性胃十二指渴潰嘎の手術後成綨について 横浜市立大学第 2 外科

$$
\begin{aligned}
& \text { 波辺 桂一, 杉山 貢, 滝沢 利男 } \\
& \text { 山中 研, 土屋 周二 }
\end{aligned}
$$

過去26年間に，われわれが手術を行った穿孔性胃十二

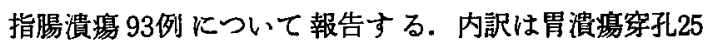

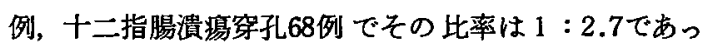
た. 性別は胃潰㵿穿孔で男：22例，女：3 例，十二指腸 潰場穿孔で男：66例，女：2 例といずれる男性に多かっ た. 好発年龄は胃潰瘍穿孔は60 69歳の高龄者群に多 く，十二指腸潰瘍穿孔は20～39藏の若年者群にピークを 認めた，胃潰瘍穿孔に対して15例に広範胃切を，1例に 胃半切兼幹迷切を，9例に穿孔部単純释合を行ない，穿 孔部単純䋖合症例中 2 例に広範胃切を 2 期的に付加し た. 術後 3 例に, 腹壁膿瘍, 腸閉塞等を併発し，また 7 例が，心不全，肺合併症等で死亡した．十二指腸潰場穿 孔に対して, 35例に広範胃切, 12例に胃半切兼幹迷切, 13 例に選近迷切，1 例に幹迷切兼幽門形成， 7 例に穿孔部 単純縫合を行ない，穿孔部単純縫合症例中 3 例に，広笧 胃切，選近迷切等を 2 期的に付加した，術後 5 例に，腹 壁膿瘍, 腸閉塞等の合併症がみられ，2 例か心心不全, 肺 合併庭等で死亡した．胃浿瘍穿孔の死亡率は $28 \%$ ，十二 指腸潰瘍穿孔の死亡率は $3 \%$ であった．但し昭和 40 年以 降，死亡例はなかった，死亡例の倹討より，高㱓者，行 前時問の遷延による汎発性腹膜炎, ショック等の合併が 予後を左右する因子之思われた。この上らな症例は手術 侵襲を少くすることが必要であるが，近年われわれは， 
十二指腸潰場穿孔14例に対して，呀孔部単純䋖合兼選近 迷切を行った，手術侵㕸む比較的少く，術後減酸効果す 良好で，現在まで潰湯の再発むみられず，十二指腸演瘍 穿孔に対して，本術式は，根治術としての適応があるる のと思われた.

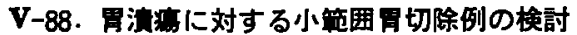
広島大学第 2 外科

蔵田 裕彦, 佐々木伸博, 福田 康彦
山根 修治, 田中 一誠, 松山 敏哉
田村 泰三, 西亀 正之, 土肥 雪彦
児玉 求, 江崎 治夫

昭和41年以来，胃溃冾に対して潰瘍の存在部位，胃液 酸度を考虑に入れた各種の小範囲胃切除を試みてきた。

胃角部以下幽門部の潰瘍には迷切兼幽門洞切除 (7 例）を行い，平均減酸率は93\%で遠隔成績む良い成績が 得られ，低酸例には幽門洞切除のみ（2 例）でも良好な 成績が得られている.

低酸の胃体部潰瘍 にはパンチフゥト切除兼幽門形成 （8 例）を行って良好な成續が得られたが，これに迷切 を加之た正酸例 (19例) では再発例が 3 例あった。

ペンチフゥト切除を行うにあたって留意すべきは胃体 下部の潰瘍例にパンチフウト切除を行った場合，術後に 砂時計様変形を示し，胃内容の停滞を伴うことであり， パンチウト切除は高位胃潰場がその良い適応となる. また術後減酸率，遠隔成䋶よりみて $\mathrm{MAO} 3 \mathrm{mEq} / \mathrm{h}$ 以 上の症例には迷切を付加することが必要である.

高位胃潰瘍のなかには胃底腺領域潰湯が含まれて括 ク，この潰煬は局所の粘膜抵抗の減弱がその発生主因で ある. したがってこれらの症例に広範囲胃切除などの過 大な手術侵襲を加えることは不必要でパソチフウト切除 または胃帯状切除が好ましい術式である。

胃体中，下部の潰場には胃体部帯状切除（10例）が適 応となるか，本法は30～50\%以上の比較的広範囲の胃体 部切除を要し, 最近ではこれに迷切を加味して切除範囲 を15 30\%にとどめる術式（7 例）を採用して満足すべ き結果を得ている.

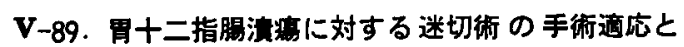
その成䖽

高松市民病院外科

$$
\text { ○西井博, 西島 早見, 佐々木文生 }
$$

藤田 博茂, 藤井 雅義, 久保添忠昭

昭和 47 年以来, 胃十二指腸潰瘍の外科的治療に迷切衍 を行なった症例は123例で同時期の広範团胃切除術に対
する割合は78.8\%となった.これらの迷切症例に対して フンケート調查を行ない $80 \%$ の回答を得た. 手術の満 足度は SV 例で91\%が Visick I， IIをしめ SPV では 82.3\%が Viscik I， IIであった. 手術前と同じ仕事を しているものは SV 例で58\%，SPV 例では84\%であっ た＼cjkstart体重が，ふえたか，または不変なるのは SV 例で $72 \%, \mathrm{SPV}$ 例では78\%であった. 現在胃腸薬を内服し ているか，の項目では，SPV 例の77\%がのんでいない が，SV 例では約50\%が服用し，厷範囲胃切除術例では 70\%が服用しつつけけていた 迷切術は術前の胃液酸度に よる基準で術式の選択はせず，胃潰愓には $\mathbf{S V}$ 兼幽門洞 切除術を，十二指腸潰嫁には SPV を全てに施行した. SPV 後のドレナージ術は多様になり簡単な幽門成形術 は50\%にすぎず前後壁幽門成形術や，Haberer 型胃十 二指腸端側吻合術， B II 方式吻合術などを行なった．こ 九は症痕性胼胝性重症十二指晹潰瘍のために一律には対 処できなかったためであった．SPV 症例がうち三症例 に潰瘍が発生した，胃潰瘍 1 例，十二指腸潰場 1 例で， $\mathrm{SPV}$ 術後3.5年, 3 年, および1.5年めであった。一例に 手術を行ない胃切除を追加し，他の二例は外来治療で潰 瘍は縮少した. 三应例は術後の減酸がわるく, Hollander テストでぎ early positive または late positive であっ た 以上により迷切手技には細心の注意をはらい，また 症痕がつ上く狭窄の強度な症例飞は SPV にこだわる ことなく臨機応変に対処すべきであると考えている.

\section{座長のまとめ 白鳥 常男}

$\mathrm{V}$ 一86と87は穿孔性胃十二指陽潰湯例に対する検討で あったが，V一86では穿孔してから十二時間以内に手術 している例が50\%前後に見られる様になったことを，さ らにV一86，87では死亡率の著しく低下してきたことを 報告しており，これは大変結構な進歩とい光よう，V一 86では穿孔部に大網を引入れた 2 例を報告していたか， これに対し座長は術後に出血しやすいと思らが，どらか との質問に対し，演者は我々もそのよ5に考之て現在行 っていないと答えたまたV一86では胃液検査を行って おり, 榊原（東京女子医大消化器）の穿孔性胃十二指腸 浿瘍を診たとき，胃液検查をなすべきでないと思うが， との質問に対 L，当然，診断がつき次第すぐに手術を行 らべきである.しかし，手術室の使用状況でたまたま術 前時間のあった 2 例に二期的に SPV を付加した 1 例の 計 3 例に胃液検查を行なったと答えていた。

Vー87では最近の 9 例に近位選迷切を行ない他の術式 
と劣らない術後成績をあげていることを報告していた が，この術式の採用について，座長からの，穿孔から手 術までの時間によって, TV，SPV などの術式の選択を 行なっているかとの質問に対し，穿孔からの時間によっ て術式選択の基準を特にもらけていない，全身状態に よってできるだけ根治的に SPVを行なっていると答 えた。 ま松木（新潟大学第 1 外科）からの被覆性潰瘍 穿孔の術前診断はどうかとの問に対し，当科です胃漬瘍 穿孔例で被覆された例を経験しているが，術前に診断は ついていないと答えた，広田（廣田胃腸病院）は術後通 過障害を起こした症例に対する 1 ～週間の保存的治㞠 の内容は1）絶食させるのか，2）胃内容を持続吸引す るのか，との質問がありこれには絶食，あるいは食事 を扎として経過をみていると述べた，関根（東北大第 1 外科）は十二指腸潰瘍の穿孔例に対して 2 例で二期的に 胃切除術などを付加しているか，その理由はどらか，ま た私は十二指腸潰湯の穿孔例では原則として幹迷切兼幽 門形成術を施行することにしているが，本術式で十分で あると考えているとの質問と追加を行なった．これに対 し演者と共同研究者の杉山は, 初回手術で突孔部単純閉 塞のみの 2 例はいずれむ関連病院よりの症例で, 他の 1 例は沉発性腹膜炎を起こしたもので，二期目に当外科で 手術したものであると答えた.

$\mathrm{V}$-88では，松木（新潟大第 1 外科）は高位潰場に対 し, 分節胃体部切除（術前の胃酸分泌態度に上りここれ に適宜迷切を併施）を韭として採用し，好結果を得てい ると追加を行なうと共に punch out のみの症例に幽成 を行ならのはなぜかと質問した。これに対し，演者は胃 潰瘍は胃内容停滞によるものと考えて pyloroplasty を 付加していると答えた。 また渡部（順天堂大）は，我々 は $\mathrm{MAO}$ が $20 \mathrm{mEq} / \mathrm{h}$ 以上の例はインスリンテストで vagal capacity が強いことより，この様な例にのみ迷切 を行なっていると追加しまた胃角部または幽門部潰 瘍で $\mathrm{MAO}$ が $7 \mathrm{mEq} / \mathrm{h}$ 以上の例に迷切を加味している が，その理由は何かと質問した。これに対し演者は迷切 +antrectomy の酸度による適応は術後の減酸率よりみ $\tau 7 \mathrm{mEq} / \mathrm{h}$ が境界となり, 高酸例に antrectomy のみと することには再発の危険性が残ると答えた.

$\mathrm{V}$-89k対して関根（東北大第 1 外科）はSPV 術 後に再発例 3 例あるが，その原因は罒門形成術の不十分 によるドレナージ，または SPV そのものの不十分な 手術手技のいずれに起因すると考えているのかと質問し た. 演者は，再発の原因は痗痕性の潰瘍に pyloroplasty
を行なったため無理があったのではないかと考えてい る. 迷切手技にる細心の注意が必要であると答えた。 た座長か演者和よびフロフーの方に対して，選近迷切に ドレナージが必要なのか,ドレナージが再発に関係した とする判定はどんな所から考えられるのか，また欧米で は十二指腸内容の逆流が再発に関係すると言っている が，再発がこれによるとする根拠のとらえ方はどうなっ ているかなどについて質問を行なったこれに対して青 木 (慈恵医大第 2 外科) は迷切後の胃漬湯の発生につい ては必ずしむドレナージ不十分とは言えず，（胃内容停 滞）逆流の問題も出てくる.したがって出来うる限り， 幽門成形をせずにすむ時期に SPV の適応を考えるべ きと思う，と答えた。をた公田(広田胃晹病院)は，

（1）術後胃内容を Stamm の胃瘦を通してて10日〜2 週 間排除している.（2）術後胃内容排出時間 は全例促 進していることを細かくX線的に追究している，（3） 夜, 就寝時, 右側卧位をとるよう指導して逆流を少なく して効果をあげている。などと答え，迷切十幽門形成術 後の胃内容排出時間は促進していることを強調してい た.

消化性溃境 II ( V-90 93) 座長 中村 卓次

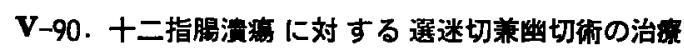
成繶

\section{千葉市立病院外科 \\ 土屋 信, 村上 和, 伊東 治武 尾崎 弘記, 沖本 光典、}

過去 5 年間に, 十二指腸潰㻛症例46例飞対して各種迷 切術を施行して来た。最近 2 年余, 選迷切兼幽門洞切除 術を基本術式として施行した34例について治療成績を報 告した.

症例は，十二指腸潰瘍27例，胃・十二指腸潰瘍 7 例， 合わせて34例である.

幽門洞切除は，血管を目安として切除し，その大きさ は, 小弯側平均 $8.2 \mathrm{~cm}$, 大弯側は $14.5 \mathrm{~cm}$ であった。

術前, 術後の胃酸分泌の推移を Tetragastrin 刺激に よる MAO でみると, 術前平均 $14.77 \mathrm{mEq} / \mathrm{h}$, 術後 1 カ 月で $1.24 \mathrm{mEq} / \mathrm{h}, 1$ 年後 $0.51 \mathrm{mEq} / \mathrm{h}, 2$ 年後 $0.24 \mathrm{mEq} / \mathrm{h}$ であった.

術後 1 力月の時点での Hollander test では, 陽性例 はない。

術直後は胃内容停滞は, 約 2 制の症例にみられたが, 保存的療法で軽快した。 また, 食慨の進め方がゆっくり である為に，胃潰弱に対する広範团胃切除例に比べて10 
日〜14日入院期間が遷延した.

法後合併症として，ダンビング症状について検討した 処，6力月後では $29 \% ， 1$ 年啳で $22 \% ， 2$ 年後 $50 \%$ と なり，比較的多いが，いずれも軽症で，一過性であり， 薬物療法等の治療を要したものはなかった，再発潰瘍は 1 例むなかった. 現在のところ良好な手術法と考光られ る.

V-91. 選迷切兼幽門洞切除術後の骨内容学滞に関す 万臨床的検討

東京女子医科大学消化器病センター外科 川田 彰得, 榊原宣

選迷切兼幽門洞切除術は確実な減酸効果を有し，乙か も術後愁訴の少ない点ですぐれた術式である.しかし術 後胃内容楌滞を来す点に問題がある. そこで当センター で施行された選迷切兼幽門洞切除術症例22例について術

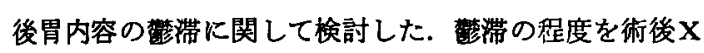
線検查で 3 段階に分類した.すなわち立位正面像で胃液 の貯留のほとんどないるのを(一)，残胃体部から噴門の 間まで胃内容が貯留乙ているものを(十), 噴門よりる上

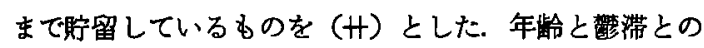
関保をみると30歳以下の群と31歳以上の群とでは前者に

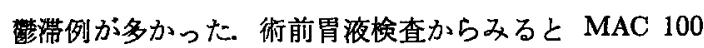

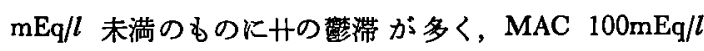
以上のものにはサが少なかった. 術前の BAO でみる と, BAO $4.0 \mathrm{mEq} / \mathrm{h}$ 未満の群でサの档滞が多かった. 術前の MAO からは, MAO $20 \mathrm{mEq} / \mathrm{h}$ 末満のものに檠 滞例が多く、またPAO $20 \mathrm{mEq} / \mathrm{h}$ 末滴のbのに整滞が 多かったすなわち術前胃分泌能の比較的低い群に術後 整滞例が多い傾向がみられた。

術後データからみると MAO 減酸率の低いむのに恶 滞が多かった. Hollander test では, positive は1例む

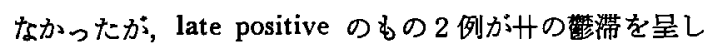
た.

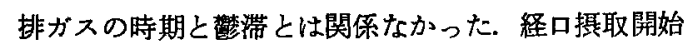

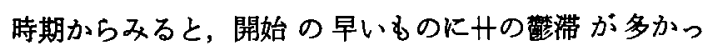
た.

術後 1 週間のメトクロプラミド投与量が, $110 \mathrm{mg}$ 以 上のむのにはサがなく, 効果があったと思われるが, $100 \mathrm{mg}$ 以下の投与量のあのでは効果は不明であった。

以上から，完全な迷切と, 術後の食䬦管理を慎重に行 ここが必要であると考えられる.

V-92. 選択的近位迷走神経切断術の臨床的問題点 東京派信病院外科
中村 哲彦, 那須 一道, 横田 稔昭

岡崎 俊典, 山崎 昭, 大野 博通

薄敬, 本間 静夫, 北原 哲夫

1973年以来78例の十二指腸潰痬に選択的近位迷走神経 切断術 (SPV) を施行し, 減酸効果, 胃排出運動, 血清 ガストリンの面から SPV の臨床的問題点について検討 した.

術後 Johnston's criterias で early positive であった 症例は technical failure として別として, negative の 症例は十分な減酸効果を維持 $し$, late positive の症例は 減酸効果不十分であった. 再発は early positive の例か ら 2 例にみられた。

胃排出運動は，誘導術を付加しなかった症例でる術後 の胃排出試験で良好な成績が得られた。しかし，術後良 好な胃排出が得られないのではないかと思われるような 著明な胃下垂を有する十二指腸潰湯に対し迷走神経幽門 洞枝温存分節的胃体部切除術を施行したところ, 満足す べき成績が得られた。

術後减酸効果不十分な late positive の症例で negative の症例より高い血清ガストリンの反応を示す症例がみら れた.これらの症例には SPV のみの減酸効果では不十 分であり，前底部切除術が必要と思われた. しかし，術 前にこれららの症例を判別する適当な方法がなく，現在血 清ガストリンの反応面から検討中である。

以上, SPV の臨床的問題点之私達の考方方, 及び胃 下垂の著明な十二指腸潰瘍に対する迷走神経幽門洞枝温 存分節的胃体部切除術について発表した.

V-93. 十二指腸溃濁 に対する選択的近位迷切術施行 後の再発消准

徳島大学第 1 外科

木下 真人, 渡辺 英生, 櫛田 俊明

森本 博文, 古味 信彦

われわれの教室では十二指腸潰陽に対する手術々式と して選択的近位迷切術（以下，選近迷切と略す）を採用 している. 選近迷切施行後の成績は怙执むね良好である が, 術後再発潰湟の発生率は他の術式にくらべて高いと 寸る報告が多い. われわれ選近迷切施行症例121例中 4 例 $(3.3 \%)$ に再発潰煌をみたので報告する.

症例 1. 30歳, 男性, 4 カ月後, 吻合部に再発, テト ラガストリン刺激による $\mathrm{MAO}$ は $11.9 \mathrm{mEq} / \mathrm{h}$, インス リンテストは early positive, 空腹時血清ガストリン值 は $25 \mathrm{pg} / \mathrm{ml}$ ，原因は通過障害と考えられ，吻合口形成術 を行った。 
症例 2.19歳, 男性, 3 年 6 カ月後, 吐血を来した。 潰榢は十二指腸に発生, MAO は $9.5 \mathrm{mEq} / \mathrm{h}$, インスリ ンテストは late から larly positive に変換した. 保存 的治療にて軽快.

症例 3. 48 歳, 男性, 2 年 4 力月後, 腹部膨満感を来 した，潰場は胃体部小弯側に発生，MAO は $0.2 \mathrm{mEq} / \mathrm{h}$, インスリンテスト negative, 保存的治療にて軽快.

症例 4.36 歳, 男性, 2 年 4 カ月後, 下血を来した. 潰偒は十二指腸に発生, MAO は $13.5 \mathrm{mEq} / \mathrm{h}$, インスリ ンテスト late positive, ガストリン值は $115 \mathrm{pg} / \mathrm{ml}$, 保存 的治療にて軽快.

文献に上る再発率は外国では0.67〜11.8\%，国内では 0.7 6.1\%の数字があげられており，他の術式にくらべ 高い再発率となっている. しかし最近, 術式の改良がな され，より広範囲の選近迷切を行うことによりどの施設 に於ても再発率は低下したと述へててい。.

以上選近迷切後の再発潰湯について自験例 4 例を報告 し, 若干の文献的考察を加えた.

\section{坐長のまとめ}

中村 卓次

十二指腸潰瘍の外科的治療として広範囲胃切除が古く から行われ，かなり良好な刘果を挙げてきた. その後迷 走神経切断術が酸分泌抑制に大きな効果があることが知 られ, truncal vagotomy, selective vagotomy, selective proximal vagotomy などが次々に登場した. 本邦でも十 数年前から迷切が一部の外科医者により行われるように なり，それにより胃切除を小範囲に止め，しかも再発防 止に役立つと主張され次第に十二指腸潰瘍の治療に応 用されるよらになってきた，幹迷切から選迷切，選近迷 切と次第にエスカレートし胃切も胃半切から胃前庭部切 除，と次第に切除範囲が小さくなり，最近では選近迷切 十幽門形成術あるいは選近迷切のみでかなり良好な成績 が報告されるようになった、V一90とVー91は選迷切 十幽切の治療成績に関する報告である. 胃内停滞がこの 方法の問題点であるが，減酸効果は良好である，V-92 とV-93は選近迷切に関する治療成績である. 選迷切に おけるよりも再発の多いことが難点として指摘された. 選近迷切ては，幹迷切や選迷切より gastric branch の 切り残しの確率が高く，それが再発につながる. 然し， 噴門部 $5 \mathrm{~cm}$ にわたる切離幽門前庭枝の一番上の枝は切 断するなど方法の改善によりなお再発は減少する可能性 があると報告された．最近米国では迷切は次第に反省期 にはいっていると聞くが，演者，floor からはまだその 傾向はらかがえなかった。

\section{序例 (V-94 98) 化長 馬场 正三 V-94. Zollinger-Ellison Syndrome $\sigma 1$ 例} 金沢大学第 2 外科

$$
\text { 米村 豊, 三輪 晃一, 山岸 満 }
$$
北村 秀夫, 松本 俊彦, 宮崎 逸夫

吻合部浿瘍穿孔により残胃再切除を行なったが, 術 後䋖合不全で死亡した Zollinger-Ellison Syndrome の 1 例を報告する。

症例は44歳男性で，家族歴に特記すべき事を認めな

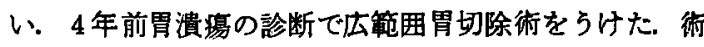
後経過は良好であったが昭和52年 8 月 15 日上腹部痛で当 科一紹介された，入院時上腹部に筋性防禦を認め，胃内 視鏡で吻合部小弯後壁に巨大な潰楬が見られた。緊急開 腹術を行なったところ吻合部潰痬は穿孔しており沉発性 腹膜炎となっていた，残胃の十分な切除を行ない手術を 終了したか，術後 1 日目より大量の胃液排出と下浰を認 めた. 術後 8 日目胃腸吻合部の䋖合不全が発生した．そ の時の Gastnin 值は $98 \mathrm{pg} / \mathrm{ml}$ であった. 術後18日目 Gastrin 值は $256 \mathrm{pg} / \mathrm{ml}$. 遊離塩酸 $56 \mathrm{mEq} / \mathrm{l}$ と增加した 為，ZES を疑い再開腹術を行なった．吻合部は完全離 断し食道に巨大な潰洦を認めたが，膵・肝・十二指腸に 腫湟は認めず，残胃全摘を行ない閉腹した。術後40日 目, Secretin 負荷テストを行なった. 前値 $420 \mathrm{pg} / \mathrm{ml}$ か らの 3 分後 710pg/ml と増加した為 ZES の確診を得た が，患者は汎発性腹膜炎に上り術後45日目死亡した。

死後膵，十二指腸を検索すると膵下縁に直径 $8 \mathrm{~mm}$ の 球形灰黄色弾性軟な腫瘤を認めた。この腫瘤は組織学的 に索状に配列するラ氏島通湯の転移リンパ節でありガス トリン蛍光抗体法にて蛍光を認めた. その他膵周囲リン パ節に転移を認めず，膵・十二指腸にも原発巣は認めな

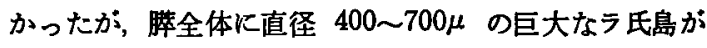
見られた.これらのラ氏島はガストリン蛍光抗体法で蛍 光は認められず，2 次的ラ氏島過形成と考えられた。転 移リンパ節内 Gastrin 含量は $20.3 \mu \mathrm{g} / \mathrm{gr} \cdot$ weight であっ た.

電顕にてコンマ型電子密度大な顆粒や，限界膜との間 に Halo を有する顆粒を認めたが，典型的ガストリン頛 粒は認めなかった。

\section{V-95. Ménétrier 病の 2 例}

名古屋大学第 2 外科

$$
\begin{aligned}
& \text { 坂本 純一, 赤塚 聡, 今泉 宗久 } \\
& \text { 市橋 秀化, 近藤 達平 }
\end{aligned}
$$

名古屋クリニック 伊藤 勝基 
症例 1 は54歳男子で，25年前より胃腫瘤， 7 年前より 低蛋白血症を指摘された患者. 全身に多発性脂肪腫があ り，20年前より輠次増加していた．昭和50年, 胃生検に て前庭部癌を確認, 胃全摘術を施行した. 切除胃は, 体 部を中心にして敬璧の巨大化, 大脳回転様変化がみら れ，組織所見で前庭部に Borrmann IV型の進行癌が確 認されたが，噴門部から 体部にかけては腫瘍細胞はな く，胃底腺粘膜の著明な増殖がみられた. 術後, 赤血 球，Ht の低下があったにすかかわらず，血清蛋白の上 昇があり， $\beta$ リポ蛋白の增加，FFA の正常化がみられ た. 免疫グロブリンも急激に上昇し, 細胞性免疫能をあ らわす PPD 皮膚反応も増強していた。

症例 2 は35歳男子で, 両下肢の浮腯にて受診, 胃 XPにて胃后瘤を指摘されたので, 胃部分切除術を施行

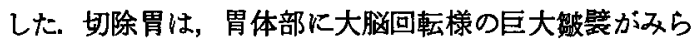
れ，前庭部に小ポりープが認められたが，悪性像は存在 していなかった. 術後, 血清蛋白の著しい上㫒がみら れ，RISA の值 む正常に復していた．免废グロブリン す急激に上昇し，PPD 皮内反応に著変はなかったが， PHA 皮内反応の増強がみられた。

本報告症例関する免疫学的検索において, 低蛋白血 症の改善と免疫グロブリン值の上昇が，術後早期に劇的 におこってくること, 開腹術後 2 週間目には通常低下が みられる細胞性免疫能のパラメーターがむしろ上昇する 傾向にあることが確認された.

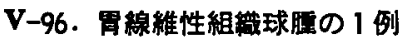

\section{国立大蔵病院 外科, 病理}

○呂 俊彦, 星長 清隆, 西堀富士夫 村上勝, 宇都宮利善, 大西 英䋇

植村 剛, 向井美知子

線維性組織球腫は，軟部組織の尰瘍として一般に四肢 に多く，その他稀に胃，肺にみられる。

最近，われわれは，胃の粘膜下に発生した腫瘍状病変 で, 組織学的に, 線維性組織球腫と訩断した極めて稀な 症例を程験したので報告する。

症例は37歳の男性で，急激な心窝部痛と発熱を主訴と して来院し, 急性腹症として緊急入院した. 胃, 十二指 腸潰瘍の穿孔を㲛ったが，腹部単純写真で free air は 証明されず，翌日には症状は軽快した，検查成績で，白 血球增多，軽度の筫血，アルカリフォスファターゼ值の 上昇がみでれた，精查をしたところ，胃レ線写真ならび に内視鏡所見で，胃体部大わん側に栗実大の粘膜下睡痬 を発見した。この間, 入院後 2 週目に再び腹痛と発熱を
認めた. 全身状態の改善をまって開腹手術を施行したと ころ，胃体中部大わん側の粘腹下に，一部大絧でおおわ

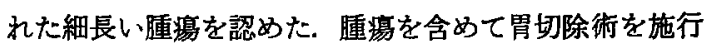
した.

切除標本で, 腫瘍は，大きさ $5.5 \times 2 \mathrm{~cm}$ の被膜を認 めた粘膜下尰瘍で，その割合は，白色と淡黄色を呈し， 一部顆粒状となっている. 壊死に陷った部分はなく，比 較的硬い充実性の尰湯であった.

病理組織所見で, 尰瘍は組織球性細胞と線維芽細胞か ら成り，その中にかなりの脂肪が含まれている，組織球 細胞は泡沫細胞として腫湯状に増殖し，その周囲にはり ンパ球や形質細胞の渻潤がみられた。 線維芽細胞の一部 は束状に配列している. 個々の細胞はよく分化してお り，異型性を示さず，全体として悪性所見はみられな かった.

以上の所見から，胃の粘膜下に発生した線維性組織球 腫と診断したそとして炎症性の反応を呈したるのとし て, 臨床症状の腹痛や発熱の原因を，この腫瘍によるも のと考えたい，胃の線維性組織球腫は，最近では欧米に 1 例の報告をみるにすぎない.

V-97. 興味ある経過を示した胃アニサキス症の 2 例 東邦大学第 3 外科 倉重 真澄, 伊藤 康一 神谷 和明, 鶴見 清彦

県央胃腸病院

矢崎 浩, 宫内倉之助, 藤本 章

昭和51年と52年に，急性アニサキス症と思われる 2 例 を経験した。

第 1 例は，47歳の女性で，イカの刺身を食した後，数 時間で心窩部痛が出現したが，我慢出来ぬ程では無かっ た. 翌日来院し, 胃レ線検査施行, 前庭部に隆起性病変 を思わせる陰影欠損があり，次の日施行せる胃内視鏡検 查で, 前庭部大弯前譬に粘膜下腫陽を思わせる隆起があ り，その隆起頂上より，粘膜内に一部穿入せる奻線虫を 生検カンシにて生存のまま採取した。 アニサキス族I型 と同定された，その後入院し，胆石症と十二指腸溃瘍に て手術を施行 L，幼線虫を採取後18日目の摘出胃が得ら れ，先述の部より，奇生虫性肉芽腫が発見された，本症 例は，臨床的に，急性アニサキス症の条件を充分に備え ているにむかかわらず，通常は，寄生虫珄肉芽腫に発展 するむのは無いと云われているので，初感染による悢和 型ではないかと我々は考えている.

第 2 例は，44藏の男性で，マグロとカツオの刺身を食 ヘてて3日目（詳細に食事歷を聴取したが，生魚は最初， 
それ以外に食していない）に心裔部痛にて来院し，翌 日，胃レ線検査を施行し，さらに翌日胃内視鏡検查も施 行した，前庭部後憵に，隆起が多発してあり，浮燠状を 呈していた，一週間後に再び，胃のレ線検查及び内視鏡 検查を施行したが，前述の病変は一切消失しており，粘 膜も正常であった. Retrospective Kレントゲンフィル ムと内視鏡のフィルムを観察すると，隆起の一つの頂上 に, アニサキス様の幼線虫が読影出来た，本症例は，虫 体を採取していないので，断言は出来ないが，臨床的に 急性胃アニサキス症と診断した，通常生体内移行後数时 間で発症していると云われている急性アニサキス症た が，本症例は 3 日たっている事が我々には説明出来ね疑 問である.

急性フニサキス症と思われる 2 例を経験し，興味ある 経過を示したのでここに報告した.

\section{V-98.アニサキス症の臨床と免疫学的研究} 札幌医科大学第 1 外科

\section{浅石 和昭, 長内 宏之, 汇端 俊彰 \\ 戸塚 守夫, 早坂 谓}

アニサキス症に関する一連の疫学調查の結果, 個体の るつ抗体保有状況により 4 型に分類された. I 型, 組 織固着抗体 $(+)$, 血中抗体 $(+)$, II 型, 組織固着抗体 $(+)$, 血中抗体 $(-)$, III型, 組織固着抗体 $(-)$, 血中 抗体 $(+), \mathrm{IV}$ 型, 組織固着抗体 $(-)$, 血中抗体 $(-)$. この抗体保有状況に上り，発症時の病態はアルサス反応， フナフィラキシー反応の両者るしくはいずれか一方の反 応で表現されるものと考えられる. 前回 (1973 75) の フンヶート調査にひきつづき, 今回 (1976〜77) の調査 結果と合わせた最近 5 年間の報告例を検討した. 胃アニ サキス症337例，腸アニサキス症46例，その他及び部位 不明10例で合計393例である. 特に北海道に和ける胃ア ニサキス症の急增が注目される.急性胃アニサキス症 は，魚介類生食後 12 時間以内に $71.2 \%$ が発症している. 加工品ではシメサバによるものが圧倒的に多い，虫体の 穿入部位は，胃ではあらゆる部位にみられ，従来腸では 回腸末端に多いとされていたが小腸のあらゆる部位に穿 入している. 起因蝀は, アニサキス:テラノーバの比 は7：3である．腸テラノーバ症は未だ報告が少ない． 全症例中 $9.8 \%$ 手術を受けているが, 特に腸つニサキ ス症の術前猃断は極めて難しいことから，現況では手術 による診断すやむをえないと思われる、アニサキス症 の発症機序に批るフナフィラキシー反応について動物 実験を行ない, Schultz-Dale 反応の発現と, 反応液中
の chemical mediator を測定した. $2 \times 10^{-6} \mathrm{M}$ という supramaximal concentration に近いヒスタミンの濃度上 昇を確認した。本症は Coombs らのいう， I 型，III型， N型アレルギーの関与が考党られる.

\section{座長のまとめ}

馬埸 正三

比較的稀な疾患の症例報告が 3 題と，アニサキス症に 関する演題が 2 題報告された.

$\mathrm{V}-94$ の演題に対しては慈恵医大第 2 外科の青木照 明先生から追加があり, Zollinger-Ellison Syndrome 自 験例 5 例中 2 例に胃全剔術を施行し，その中の 1 例は malignant な症例で肝転移を認めたが，術後 5 年を経 て転移巣の自然退行縮少を認めており, 胃全剔により “Gastric factor”がなくなったためと考えているとの comment があった.

又広田胃腸病院広田和俊先生から再手術時の術式に関 する質問があった。

V一95の Ménéctrier 病の 2 症例の中 1 例は Follow up 中に Biopsy により胃癌を術前に骖断し得た貴重な 症例であり, Ménétrier 病に関する文献的考察が行われ た.

$\mathrm{V}$ 一96は胃線維性組織球腫に関するるので他の粘瞙下 腫湟との鑑別点が述べられた。

演題Vー97と98はアニサキス症に関するもので, 演者 間で質疑応答がなされた。

特に急性アニサキス症で寄生虫性肉芽腫を認めた症例 1 つにいて，検討が行われた。

虫体が存在しない肉芽腫形成型の臨床例は少ないが， 臨床症状から考えて I 型, IV型アレルギーの共存と理解 されるとの comment が札幌医大第 1 外科, 浅石和昭先 生からなされ，北海道岩内町の石倉簕先生からは「第 1 例の組織に肉芽腫形成があったことについては，摘出し た生きた虫体によるものか，既に生じていた前回の幼虫 によるるのか判断はむつかしいが，動物実験では一回の 侵入です肉芽腫が出来るので, 人体症例です肉芽腫が出 来ても不思議はない」との意見が述べられた。

消化器検查・手街 $(\mathbf{V}$-99 103) 座長 石川 義信

V-99. 消化器疾息における術中乾楾近接层影の店用 横浜市立大学第 1 外科

$\begin{array}{lll}\text { 富田 } & \text { 康彦, 赤池 } & \text { 信, 藤本 泰則 } \\ \text { 天野 } & \text { 富暴, 後藤 } & \text { 久, 小泉 博義 } \\ \text { 五島 } & \text { 英迪 }\end{array}$

消化器手術に䟢し, 開腹後, その所見により手術々式 の選択を迫られることがしばしばある.病巣を中心とし 
た周囲組織の病変を知る手段として，我々は，術中軟線 近接撮影を応用している.

その方法は，予め用意した種々の大きさの乳房撮影用 フィルムを標的䑏器に密着し，造影を併せて顿線撮影を 行なら方法である.

現在まで, 䏣石症, 消化器癌, 食道静脈瘤等を対象と している.

胆道系の手術に際し, 術中胆道造影は術式の選択, 手 衍効果の確想などには欠く事の出来ない恰査法である. 従来の掫影法では，微細病変の描出には限界があり，混 入気泡の誤認，遗残結石など皆然ではない，従来の撮影 法に加党，術中軟線近接撮影を行なっている.

コッヘルの授動後, 乳房撮影用フィルムを総胆管に密 着し軟線撮影施行, より鮮明な像を描出し病変の判続に 供している. 今後は，術中胆道フォイバーも大いに利用 すべきと考兄ている。

胃疾患に対するX線診断, 内視鏡詥断は著しい進歩を 示しているが，これらは粘膜面よりの診断法であり，胃 壁内の浸潤範囲は完全には診断しえない，術中軟線近接 撮影にて鮮明なマイクロアンギオグラムを描出し, 癌の 壁内浸潤範囲の訩断に応用を試みている，方法は乳房撮 影用フィルムを目的とする病巣の背面に密着させ, 空気 にて胃前後壁の重なりをとり, 胃壁を伸展させた後, 支 配動脈より血管造影を行なら，食道静脈瘤については， すでて報告したが，本法での他の消化器疾患での有用性 について報告した。

V-100. 外科的治療に内視鏡的治療を併用した 2 症 例

\begin{tabular}{|c|c|c|c|}
\hline \multicolumn{4}{|c|}{ 筑波大学臨床医学系外科 } \\
\hline ○高瀬 & 靖広, 艘 & 健, 名越 & 和夫 \\
\hline 更科 & 広実, 竹島 & 徹, 尾崎 & 梓 \\
\hline 潹尾 & 立, 岡村 & 隆夫, 岩崎 & 洋治 \\
\hline 声里 & 清隆 & & \\
\hline
\end{tabular}

外科的治療に内視鏡的治療法を併用して，手術侵襲を より少なく治療しえたと考えられる 2 症例について報告 した.

第 1 例は56歳女性で，胃体部前壁の I c 型早期胃癌， 十二指腸2nd loop 前壁の山田IV型の adenomatous polyp, 総胆管結石（1 個）および䏣丵結石の是いと診断した 症例である. 本例では早期胃癌は比較的胃体部高位にあ り，外科的には胃幽門側严全摘術の適応と思われたが， 胃全摘の可能性もあると考えられた。 また，十二指腸ポ リープは形，位置から内視鏡的ポリペクトミーは容易之
思われ，総胆管結石む比較的小さいので内視鏡的パピロ トミーによって消失しらると考えられたので，手術侵襲 の軽減をはかる目的で，内視鏡的ポリペクトミーおよび パピロトミーを施行した，その結果，十二指腸ポリープ と総胆管結石は容易に治療されたので，早期胃癌に対す る外科的治療にらつり，胃幽門側亜全摘術を行ない，同 時に術中胆のう結石が双とめられたので胆霍摘除術を施 行した.

第 2 例は 63 歳女性で叶血・下血を反復した食道静脈瘦 症例である.脾腫は中等度で，肝機能障害は強くなく， ICG 值12\%（15分值）であったしかし，40年前の結 核性肋膜炎と脊椎カリェスによって肋膜肥厚著しく，脊 椎も第12胸椎を中心に強い Gibbus を形成しており肺機 能む\% V.C. $56 \%$ でるなど拘束性換気障害が著しいの で食道離断術を断念して, 食道静脈瘤に対して内視鏡的 治療を行ったそそして外科的には脾摘と一部血行遊清を 行った.

以上， 2 症例も経過良好でありますが，外科的治療に 内視鏡的治療を併用して手術侵襲の軽減がはかられたと 考えている.

V-101. 消化性溃湯手術患者のバイクル糸，テキン ン糸の吸収に関する検討

広田胃腸病院（横浜市）

広田 和俊, 大矢 和光

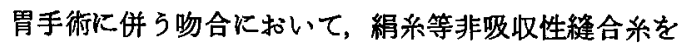
用いると，術後系に起因する出血中狭窄に遭遇するこ とがある.そこで1974年から合成吸収性縫合系である Vicryl を1335回，Dexon を668回，合計2023回の消化管 手術に用いてきた．これまでの報告では，筋組織や動物 実験によって Vicryl が42日から70日の間に，Dexon は 70 日から130日の間に吸収されると報告されているが, 胃手術の際には，胃液や胆汁，粕液等十二指腸液による 分解吸収を受けて，吸収時間に対する影響が考えられ る. そこで37症例の胃手術患者に打いて，次の方法で㭘 討した、いずれ子後壁の縫合が終ったところで Vicryl， Dexon, Catgut, 綟糸を針系の結節縫合をおいて，そこに Hemoclip を㣣み，系の吸収，断裂によって，Clip の消 失を術後X線的に観察したものである. その結果 Catgut では7 日から20日の間に吸収され，平均13日であり， Vicryl は11日から47日，平均28日であって，Dexon は13 日から47日の間，平均30日であった. Vicryl む Dexon も絧采や Catgut より切断までの抗張力が強く，かつ 病理組織学的反応を見てる, 術後 3 週と 5 週に和いて 
Catgut や絹糸よりる炎症性細胞の渗潤が少なかった. これらの知見 と臨床経験から，上部消化管吻合におい て, Vicryl, Dexon 共に適切な期間で吸収される稀合采 であり，絧糸や Catgut に代って用いられるべき材料で あると結論した。

V-102. 各程消化管手彷に対する Gambee 一尼畅 合の臨床的検討

愛知医大第 1 外科 金光 泰石

消化管手術には繾合不全や吻合部狭害等の術後合併症 がありこれに対処するため種々な努力がはらわれてい る. 近年創傷治瘾機転の解明とともに再び手術器材や吻 合手技の改善について関心が高まり，特に手技として断 端复合を重視する一層吻合法を合理的とする報告がみら れている，我々は102例の各種消化管疾患に対し108回の Gambee 一層吻合術を施行した。

手術対象は贯・十二指腸潰湯43例, 胃癌24例, 大腸癌 17例等の計102症例で，その年龄分布は広く10代より80 代にわたった。

吻合術式別にみると，胃と十二指腸又は空腸との吻合 が20例, 幽門形成術13例, 食道と胃又は空腸之の吻合 7 例，総胆管，十二指腸吻合 4 例，小腸と小腸又は結腸 と の吻合11例，結腸と結腸 との吻合20例の計108例であっ た.

栄養状態と貧血は䋖合不全と密接な関係のある因子で あり,この点について検討した. 創傷治瘱機転を要延す るとされている $6 \mathrm{~g} / \mathrm{dl}$ 以下の症例は30例で又全体の約半 数が貧血症例で, 特に300万以下の貧血症例は20例もあ ったが，縫合不全は全く経験しなかった。

吻合手技に関する術後合併症として問題になる吻合口 狭窄，吻合部出血についても検討したがいずれる1例す 認められなかった。

Gambee 一層吻合法は手技的に決して困難なるのでは なく, 血管に富み, 又抗張力の強い粘膜下層の瘾合を重 視するため創第治瘦か的確に行われ, 従って䋖合不全が 少なく，又一層吻合であるため吻合端の血行障害が少な く, 且つ内翻組織が少ないため狭合口狭窄等の術後合併 症を来たしにくい理想的な吻合法と判断された.

V-103. 晹管器㙨吻合の臨床释験とその手技的検討 東京医科歯科大学第 2 外科

○安田 嵫, 平山 廉三, 捠田 節雄 名越 正樹, 宮永 忠彦, 宇都宮譲二 浅野 献一

近年, 腹部外科領域において手術の拡大に伴ない, 深
く狭い術野での吻合操作が要求され，吻合術式の改良と 共に各種器械による腸管吻合か導入され多くの臨床報告 が行われている.

われわれはフンドロゾフ式自動離断吻合器を用いて, 動物実験により吻合創部の治㾤状況を形態学的に観察 し，その特性を探った

器械吻合は全周性に均一に且つ確実に縫合され, Albert-Lembert 法に比ぺて，炎症所見が少なく，粘膜 の再生す早い，血管の新生すより豊富で成熟の過程す早 く，むしろ層別䋖合に逬色ない良好な実験結果を得た。

吻合器使用にあたり，吻合操作をより短時間に且つ確 実に行なうためには，必要最小限の腸管断端を全周性 に均一に器械に固定する事が最も重要と考光, prolene (polypropylen) 禾を用いた “edge suture”を工夫した。 これを用いることにより従来より短時間に，且つ円滑に 吻合操作が行ない得た。

教室での器械吻合症例は20例で，そのうち 2 例に艇合 不全を認めた。これらは，いずれも低位直腸前方切除術 例で, 器械操作の初歩的ミスにより, staple の折曲か悪 いために起きたもので, 保存的に軽快した.

また軽度の吻合部狭窄を来したものもあるが,ブジー ルング等により軽快している.

最後に，器械吻合部の肉眼所見の経過を観察した 1 症 例を供覧した，術後 2 週目では吻合部にビラン潧湟等な く，2カ月目では完全に粘膜は上皮化され炎症所見むな く，手程いに比較しても释過は良好といえる.

以上，実験的にも臨床的にも器械吻合創部は良好な治 瘾を営むと考えられる.

\section{座長のまとめ}

石川 信

Vー99ないしV-103では消化器検査・手術に関する 比較的新らしい手法に関することが論じられた. 富田康 彦氏（横浜市立大 1 外科）は, 胆石 - 門脈圧六進・消化 器癌等について, 術中軟 $\mathrm{X}$ 線撮影により病巣の詳しい情 報を得んとし (V-99), 高瀬靖広氏（筑波大学臨床医 学系外科) は, 消化器手術に内視鏡的治療を併用して, 少ない侵襲で目的を達しようとして $(V-100)$ ，共に良 好な結果を得ていると報告している. 広田和俊他（横 浜市広田胃腸病院）は, Vicryl, Dexon 等の合成吸收性 䋖合糸を消化管䋖合手術に用いた場合は 3 ないし 6 週で 消失することを確め，従来の綟系・Catgut より有利で あるとしていた. 岩崎洋治氏（筑波大学外科）は, 使用 縫合材料の消失期のばらつきの多いことに関する演者の 
見解を求めたが，演者は胃液酵素之の間には相関をつか めなかったとしていた $(V-101)$. 金光秦石氏他（愛知 医大 1 外) は108例 の各種消化管の Gambee 一層吻合

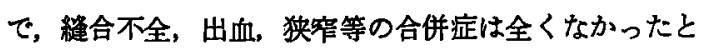
述べ，丸山圭一氏(国立がんセンター外科)の low anterior resection の場合の成績に関する質問に対し，演 者は低位前方切除で特にこの方法が有効であったとして いる. 又 Gambee 吻合の所要時の質問に対しては, Albert-Lembert 吻合の約 2/3であると述べた (V-102). 安田滋氏他 (東京医科歯科大学 2 外科) はフンドロゾフ 自動離断吻合器の直腸前方切除, 食道離断, 食道空腸吻 合時の使用について良好な成績を述へ，polypropylene 糸使用による edge suture で腸管を全周性に確実に器械 に固定することと，吻合器拔去時に無理のないよら習熟 することの重要性を述べた。田村謙二氏（平塚市民病院 外科）は，66例の使用例中 5 例に leak をみたか，いず れむ 2 週間の禁食で軽快したと追加し，又西村昭男氏 (日本製鋼所病院) は北大 1 外科式のクリッブ吻合器を 200回以上の消化管吻合に用いて演者之同様の結果を得 たが，吻合部拡張力で数倍すぐれていたと述べた（V一 103). 